\title{
ADDITÍV GYÁRTÁSI TECHNOLÓGIÁKKAL MEGVALÓSÍTHATÓ TÖMEGCSÖKKENTŐ RÁCSSZERKEZETEK GEOMETRIAI MODELLEZÉSÉNEK LEHETŐSÉGEI
}

\section{POSSIBILITIES FOR GEOMETRIC MODELING OF WEIGHT REDUCING GRID STRUCTURES MADE BY ADDITIVE MANUFACTURING TECHNOLOGIES}

\author{
Sándor Roland ${ }^{1 *}$ \\ 1 Jármütechnológia Tanszék, GAMF Müszaki és Informatikai Kar, Neumann János Egyetem, Magyarország \\ https://doi.org/10.47833/2020.2.ENG.003
}

\section{Kulcsszavak: \\ additív gyártási \\ tömegcsökkentés \\ vizuális programozás}

\section{Keywords:}

additive manufacturing

mass reduction

visual programing

\section{Cikktörténet:}

Beérkezett 2020. június 10.

Átdolgozva 2020. június 20.

Elfogadva 2020. július 1.

\begin{abstract}
Összefoglalás
Az additív gyártási technológiák gyors fejlödésének köszönhetően új lehetöségek nyilltak meg a gépipari gyártmányok tömegének csökkentését célzó gépelem kialakitások alkalmazására. Olyan rács jellegü alaksajátosságok ezek, melyeket az eddig járatos gépgyártási technológiákkal csak nagyon költségesen vagy egyáltalán nem tudtunk előállítani. A cikk egy lehetséges megoldást tár fel ezen rácsszerkezetek CAD szoftverekben készített gépelem modellekben történő alkalmazására. A módszer alkalmazásával lehetségesé válik tetszőleges geometriai modell, változtatható geometriai paraméterekkel bíró rácsszerkezettel történő, tömegcsökkentést célzó átalakítása.
\end{abstract}

\begin{abstract}
Thanks to the rapid development of additive manufacturing technologies, new possibilities have been opened for the use of machine element designs to reduce the weight of mechanical engineering products. These are grid-like features that we have not been able to produce very costly, or at all, with the prior art manufacturing technology. This article explores a possible solution for using these lattice structures in machine tool models made in CAD software. By applying this method, it is possible to transform any geometric model with a lattice structure with variable geometry parameters for weight reduction.
\end{abstract}

\section{Bevezetés}

A jármüipar és a repülögépipar területein mindíg is nagy hangsúlyt fektettek a gépipari konstrukciók tömegének csökkentésére. A gyártási technológiák és az anyagtudomány fejlődésével a közelmúltban is új lehetőségek nyíltak ezen cél korszerü megvalósítására. A különböző additív

\footnotetext{
* Kapcsolattartó szerző: E-mail: sandor.roland@gamf.uni-neumann.hu
} 
gyártási technológiák gyors fejlödése révén olyan bonyolult geometriai struktúrák gyártási is lehetővé vált, ami korábban elképzelhetetlen volt. Ezen gyártási technológiák közül a gépiparban legnagyobb jelentősége a Direct Metal Laser Sintering technológiának van. Ezzel a technológiával lehetővé vált bonyolult geometriájú fém alkatrészek gyártási. Olyan nagy teherbírású alkatrészek gyárthatók így amelyek könnyített rácsszerkezettel rendelkeznek (1-2. ábra). Ezáltal tömegük töredéke a hagyományos technológiákkal gyártott azonos teherbírású alkatrészeknek. Felvetődik azonban a kérdés, hogy hogyan tervezhetünk tömegcsökkentő rácsszerkezetet a különböző geometriai jellemzőkkel rendelkező alkatrészekhez. Alábbiakban egy lehetséges megoldás ismertetése történik.
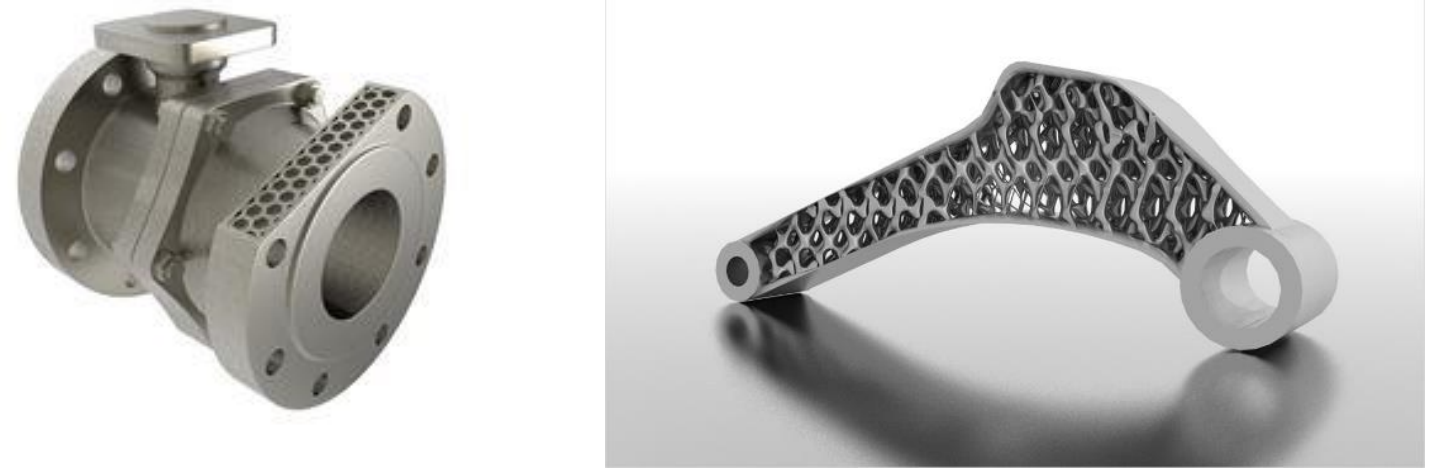

1. ábra Példa rácsszerkezettel könnyített gépipari gyártmányokra

\section{A vizuális programozás módszereinek alkalmazása a modellalkotásban}

A vizuális programozás eszközei lehetővé teszik, hogy a felhasználó egy szoftver alapeszközeit tetszőleges módon kombinálva saját algoritmusokat készítsen programozói háttérismeret nélkül. A hab struktúra geometriai modelljét létrehozó algoritmus elkészítése a Rhinoceros 3D nevü szoftver Grasshopper névre hallgató moduljában történt. Az említett modul lehetővé teszi, hogy a felhasználó az alapszoftver eszközeit elérje funkció blokkok formájában (2. ábra). Minden funkcióblokknak vannak kimenetei és bemenetei. A funkció blokkok ki és bemeneteit vonalakkal köthetjük össze ezzel adva meg a blokkok közötti kapcsolat jellegét. Az elérhető blokkok között vannak, amelyek egészen egyszerü műveleteket végeznek, például összeadják a bemenetekre kötött szám jellegű változókat, és vannak egészen bonyolultak is melyek iterációs számítást végeznek egy célparaméter elérése érdekében. Ez a blokkdiagrammos felépítés lehetővé teszi paraméteres modellek elkészítését bonyolult, organikus formák esetén is.

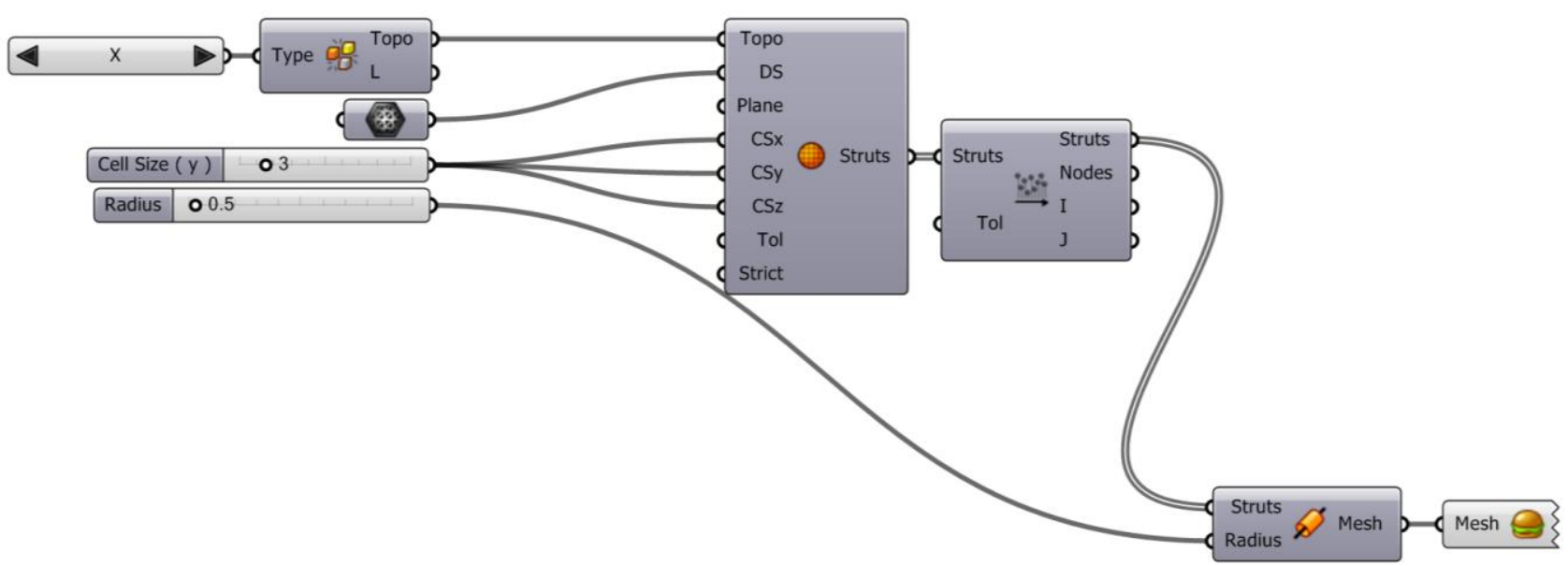

2. ábra A modelt eredményező algoritmus blokk diagramja 


\section{A geometriai modell alkotás folyamata}

A geometriai modell alkotás során az algoritmus megnyitja a CAD szoftverben elkészített modelt mely tetszöleges alaksajátosságokkal rendelkezik (3a ábra). Ezt követően meghatározza azt a téglatestet, amelybe a megnyitott modell pontosan illeszkedik. Ebben a téglatest formájú tartományban általunk meghatározott típusú rácsot generál. Az így kapott rácsnak tetszőleges vastagságot adhatunk. A rácsot alkotó cellák méretét és számát szintén a felhasználó határozza meg. A rács vastagsága valamint a cellaméret befolyásolja a tömegcsökkenés mértékét. $A z$ algoritmus által generált rácsot ezt követően tetszölegesen ötvözhetjük CAD modellekkel így elérhető, hogy az alkatrész bizonyos részei tömörek, míg más részei ráccsal könnyítettek legyenek. Az algoritmus rugalmassága révén megoldható, hogy a leendő gyártmány fokozottabb terhelésnek kitett részein a rácsvastagság folyamatos átmenettel növekedjen. A feszültséggyüjtő helyek számának csökkentése érdekében megadhatunk egy sugár értéket is és így a rács valamint a tömör fal találkozásánál nem keletkeznek éles sarkok. Ez nagymértékben javítja a gyártmány élettartamát.
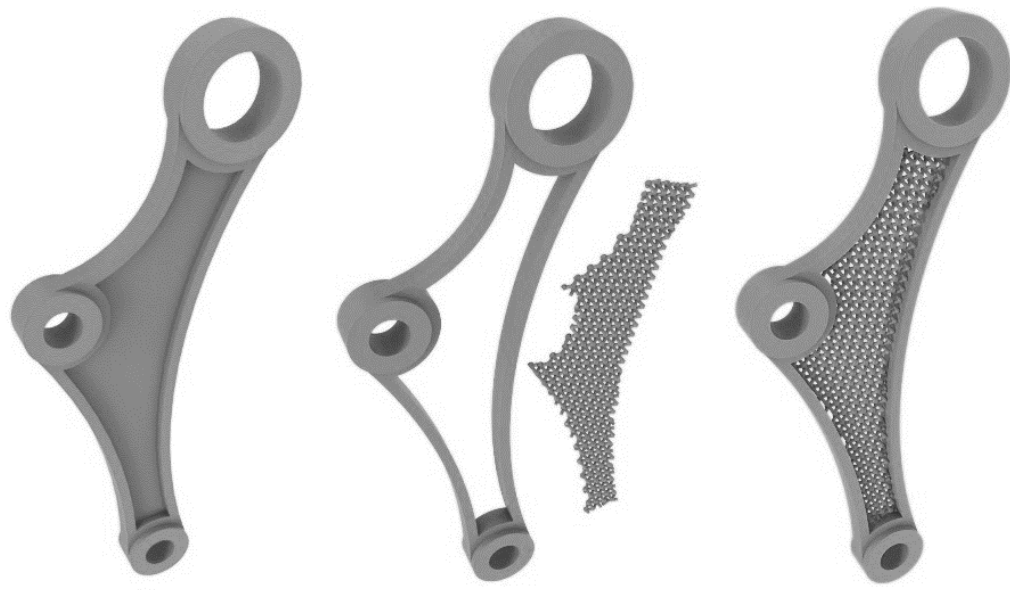

3. ábra Modellalkotás lépései

\section{Alkalmazható rácstípusok}

Az algoritmus álltál kigenerált rácsszerkezet jellegének egy fontos kritériumnak kell teljesülni. Kulcsfontosságú hogy a rács elemi cellái tudjanak kapcsolódni egymással, mivel a szoftver a rács létrehozását elemi cellák kiosztásával végzi. Fontos tehát, hogy a megtervezett elemi cella szimmetrikus legyen. (4. ábra) Az egyes cella típusok nem csak jellegükben, hanem ebből adódóan a kitöltési tényezőjükben és a statikus valamint dinamikus igénybevétellel szembeni teherbírásukban is eltérnek egymástól. Az adott felhasználásra alkalmas rácsszerkezet megtervezésének fontos része az cellákat alkotó anyag vastagságának meghatározása. A szükséges anyagvastagságot befolyásolja az alkalmazott cella megválasztott mérete, a cellák típusa valamint a tervezett mechanikai igénybevétel nagysága. A mechanikai terhelés ismeretében egyértelmüen meghatározható a minimálisan szükséges teherviselö keresztmetszet. Ugyan azt a teherviselö keresztmetszetet azonban létrehozhatjuk több cella méret, anyagvastagság kombináció eredményeként is. Az anyagvastagság maximális értékét a cella mérete és jellege határozza meg, míg minimumát leginkább az alkalmazni kívánt technológia befolyásolja. A jelenlegi technológiai feltételek mellett Direct Metal Laser Sintering technológiával a legkisebb legyártható anyagvastagság $1 \mathrm{~mm}$, de ezt a felhasznált alapanyag tulajdonságai is befolyásolják.
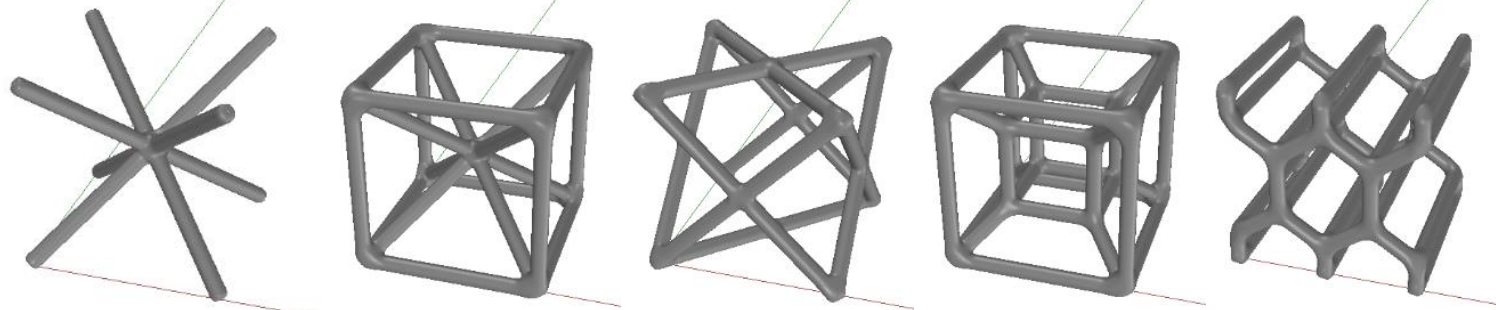

4.ábra Néhány példa alkalmazható elemi cellára 


\section{Ráccsal könnyített modellek felhasználhatósága}

Az így kopott modell alkalmas végeselemes szimulációk elvégzésére alkalmas szoftverekben történő további felhasználásra vagy additív gyártásra. Az algoritmus lefutása után egy háromszögekből álló, úgynevezett „mesh” modelt kapunk. Fontos azonban meggyőződni arról, hogy a modellt alkotó rács nem tartalmaz hibákat. Előfordulhat ugyanis, hogy számítási hibák miatt hiányzó felületek vagy egymást metsző felületek jelentkeznek a modellen. Ebben az esetben a későbbiek során az additív gyártó berendezés szoftvere nem fogja tudni elvégezni a gyártáshoz szükséges szerszámpálya meghatározását, (5. ábra) mivel a modellt alkotó felületek nem határoznak meg zárt keresztmetszeteket.
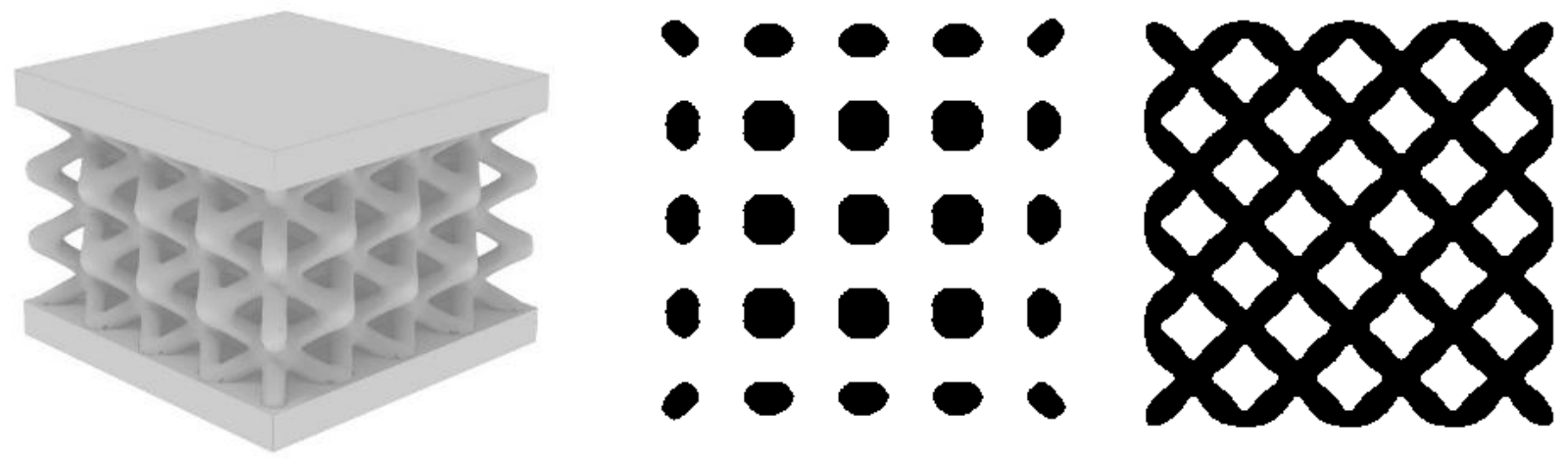

5.ábra Rácsszerkezettel könnyített 3D modell és annak jellemző keresztmetszetei

Az ilyen hibák sokkal ritkábban jelentkeznek kis felbontású, kevés poligonból álló modellek esetén. Célszerű tehát a modell felbontását a lehető legkisebb értéken tartani. Ezzel nem csak az esetleges rácshibák esélyét csökkentjük, hanem a modellalkotáshoz szükséges számítási teljesítmény igényét is. Azonban ha a modell felbontása túl alacsony, akkor a gyártmány geometriai pontatlansága is nagyobb lesz. A modell rácshibái könnyen tetten érhetőek a tárgyalt algoritmus segítségével, egy funkcióblokkal mely megvizsgálja, hogy vannak-e egymást metsző vagy hiányzó felületek.

Amennyiben az elkészült modelt CAD szoftverben szeretnénk felhasználni, például összeállítási modell készítéséhez, akkor el kell végeznünk egy átalakítást a modellen, mely szilárd test modelt készít a meglévő mesh modellből. Ennek módja, hogy a modelt alkotó háromszögeket úgy nevezett „NURBS” felületekké alakítjuk egy erre a célra alkalmas funkcióblokkal a vizuális programozást lehetővé tevő felületen belül. Az így kapott felület modelt pedig szilárd test modellé alakítás parancs segítségével olyan formába tudjuk hozni, mely alkalmas a későbbiekben arra, hogy a CAD szoftverben geometriai kényszerek segítségével megadjuk a ráccsal könnyített alkatrész, többi alkatrészhez füződő viszonyát.

\section{Köszönetnyilvánítás}

A projekt az Európai Unió támogatásával, az Európai Szociális Alap társfinanszírozásával valósul meg. EFOP-3.6.1-16-2016-00014

The project has been supported by the European Union, co-financed by the European Social Fund. EFOP-3.6.1-16-2016-00014.

\section{Irodalomjegyzék}

[1] 3D printed metal tray 24 May 2019 https://www.materialstoday.com/additive-manufacturing/products/3d-printed-metal-tray/ (Utolsó letöltés: 2020. 06. 03.)

[2] [Autodesk Autodesk's "Within" Could Generate Industrial Change 2015 https://www.fabbaloo.com/blog/2015/7/18/autodesks-within-could-generate-industrial-change (Utolsó letöltés: 2020. 06. 03.)

[3] Interlattice Overview http://intralattice.com/overview/ (Utolsó letöltés: 2020. 06. 03.) 